\title{
THE FORMATION OF PROTOPLASTS FROM MUCOR SPECIES
}

\author{
by \\ ROBYN VAN HEESWIJCK
}

\author{
Chr. Hansen's Laboratorium A/S, \\ Sankt Annæ Plads 3, DK-1250 Copenhagen K \\ and \\ Department of Physiology, Carlsberg Laboratory, \\ Gamle Carlsbergvej 10, DK-2500 Copenhagen Valby.
}

Keywords: Fungal protoplasts, chitosanase

\begin{abstract}
Methods were developed for the reproducible production of high yields of stable protoplasts from mesophilic and thermophilic strains of Mucor. This is a pre-requisite for the genetic analysis and manipulation of Mucor by cell fusion or transformation and is of special importance in these species since conventional genetic analysis by recombination studies is not feasible. The cell wall lytic enzyme used was the concentrated culture fluid of Streptomyces sp no. 6 grown on chitosan and chitin. Using germlings of M. circinelloides f. Jusitanicus the optimum conditions for protoplast formation were determined as: $0.5-1.0 \mathrm{mg} \cdot \mathrm{ml}^{-1}$ streptozyme $\left(1.2\right.$ units chitosanase $\left.\cdot \mathrm{ml}^{-1}\right)$ plus $2.0 \mathrm{mg} \cdot \mathrm{ml}^{-1}$ novozym 234 or $1 \%(\mathrm{v} / \mathrm{v})$ helicase in $0.5 \mathrm{M}$-sorbitol, $0.01 \mathrm{M}$-sodium phosphate buffer, $\mathrm{pH} 6.5$ for 3-4 hours at $23{ }^{\circ} \mathrm{C}$. Treatment of $10^{7} \cdot \mathrm{ml}^{-1}$ germlings gave yields of up to $3 \times 10^{7} \cdot \mathrm{mI}^{-1}$ protoplasts with regeneration and fusion frequencies of up to $40 \%$ and $1.7 \%$, respectively. With the thermophilic strains growth at low temperature $\left(25^{\circ} \mathrm{C}\right)$ was critical for the subsequent formation of stable protoplasts. Synchronous growth and germination was obtained at this temperature by a short pre-incubation (1-3 hours) of the sporangiospores at $40^{\circ} \mathrm{C}$.
\end{abstract}

\section{INTRODUCTION}

The filamentous fungi belonging to genus Mucor are of biochemical and industrial interest. This is primarily because of the production by certain species of a number of extracellular enzymes such as acid proteases $(3,27)$, lipases (37), amylases (2) and cellulases (36). In addition, they provide a useful system for the study of the biochemical basis of morphogenesis since some species can be induced to undergo a morphogenetic change from hyphal to budding yeast-like growth in response to various environmental stimuli (4). The genetic analysis of Mucor species and any mutants derived therefrom is hampered by the difficulties in utilising the sexual cycle of these organisms. Mating of $(+)$ and (-) strains does not always result in the formation of zygospores, and in some species the numbers produced are low while in others their development remains incomplete (34). Moreover, the successful germination of zygospores under laboratory conditions is rare and is preceded by a considerable period of dormancy (12, 14,42 ). Formal genetic analysis by recombination studies is thus not feasible. In this context the study of protoplast formation in Mucor becomes of special interest since the alternative genetic techniques of cell fusion and transformation depend in most cases on the availability of large numbers of viable protoplasts. The efficient transformation of Mucor circinelloides by incubation of protoplasts with plasmid DNA in the presence of polyethylene glycol and $\mathrm{CaCl}_{2}$ is reported in an accompanying paper (18). 
The formation of protoplasts requires the removal of the cell wall by digestion with a lytic enzyme(s). The vegetative spores (sporangiospores) of Mucor are not a suitable source of protoplasts due to the extreme resistance of the cell wall to lytic digestion (20). The high content of melanin ( $10 \%$ dry weight) (5) is implicated in this resistance (20) as it is a known inhibitor of cell wall lytic enzymes (11). During germination, a vegetative wall is formed de novo underneath the sporangiospore wall, later emerging to become the germ tube wall (6). The lack of continuity between the spore and vegetative walls is correlated with marked differences in their composition, including the absence of melanin in the latter. Chitin and chitosan become the main components; in $\mathrm{M}$. rouxii for example they constitute $9.4 \%$ and $32.7 \%$ of the hyphal cell wall, respectively (5). Chitinases isolated from several sources are available com. mercially but they are unable or only partially able to hydrolyse chitosan. Chitosanases are not yet commercially available but are produced as extracellular enzymes by a variety of microorganisms $(17,24,26,28)$. The culture fluids from some of these microorganisms, or the chitosanases purified therefrom, can digest the hyphal cell walls of Mucor $(20,28,30)$ and enable the formation of protoplasts from Mucor $(15,22$, 26, 30) and the related genus Phycomyces (9). The present paper reports the successful formation of protoplasts from a number of Mucor species using the concentrated culture fluid of Streptomyces $\mathrm{sp}$. no. 6 . The effects of some parameters are examined in order to maximise protoplast yields and the various methods reported for streptozyme preparation are compared.

\section{MATERIALS AND METHODS}

\subsection{Strains}

Streptomyces sp. no. 6 was obtained from D. JONES (the Macaulay Institute for Soil Research, Aberdeen, Scotland). Strains of Mucor used were the mesophiles Mucor circinelloides f. lusitanicus CBS 277.49 ( $=$ M. racemosus ATCC $1216 \mathrm{~b}$ (33)), M. racemosus no. 50 (19) and $M$. rouxii CBS 416.77 and the thermophiles $M$. miehei CBS 182.67, M. miehei CBS 370.65, and
M. pusillus IMI 96211. The auxotrophic mutants used in protoplast fusion experiments were isolated after mutagenic treatment of $\mathbf{M}$. circinelloides f. lusitanicus CBS 277.49 sporangiospores with UV-irradiation in this laboratory by Dr. M.I.G. RONCERO (31).

\subsection{Chemicals}

Unless stated otherwise, all chemicals were supplied by Sigma. The chitin and chitosan were of practical grade prepared from crab shells. The enzymes used in section 3.2 .1 (iv) and their sources were: novozym 234 (prepared from Trichoderma harzianum, mainly containing $a-$ 1,3 glucanase activity, received as a gift from Novo Industries A/S, Denmark), helicase (L'Industrie Biologique, France), laminarinase ( $\beta-1,3$ glucanase ex mollusca, Calbiochem, U.S.A.), $\beta$-glucanase isolated from Penicillium emersonii (BDH Biochemicals, England) and chitinase (Sigma, activity $=3.0$ units $\cdot \mathrm{mg}^{-1}$ ).

\subsection{Media}

The complete medium used was YPG $(3 \mathrm{~g}$ yeast extract, $10 \mathrm{~g}$ peptone and $20 \mathrm{~g}$ glucose per litre distilled $\mathrm{H}_{2} \mathrm{O}$ ). The minimal medium was YNB $(0.5 \mathrm{~g}$ Difco yeast nitrogen base $w / 0$ amino acids and ammonium sulphate, $1.5 \mathrm{~g}$ ammonium sulphate, $1.5 \mathrm{~g}$ elutamic acid per litre distilled $\mathrm{H}_{2} \mathrm{O}$ with $1 \%$ glucose and $1 \mu \mathrm{g} \cdot \mathrm{ml}^{-1}$ thiamine and niacin added post sterilization). The media were adjusted to $\mathrm{pH} 4.5$ with $1 \mathrm{M}-\mathrm{HCl}$ unless restricted colony growth was required (for viability counts, detection of heterokaryons) in which case the media were adjusted to $\mathrm{pH} 3.0$. $20 \mathrm{~g} \cdot \mathrm{I}^{-1}$ agar was included for solid media, and in the case of $\mathrm{pH} 3.0$ media, double strength solutions of agar and the other media components were autoclaved separately to avoid acid hydrolysis of the agar.

\subsection{Isolation and assay of Streptozyme from} Streptomyces sp. no. 6

Streptomyces sp. no. 6 was grown for $7-8$ days at room temperature in the medium of SKUJINS et al. (35) with $0.5 \%(\mathrm{w} / \mathrm{v})$ chitin and $0.1 \%(\mathrm{w} / \mathrm{v})$ reprecipitated chitosan (chitosan dissolved in 
$1 \%$ acetic acid, neutralized with $\mathrm{NaOH}$ then washed extensively with $\mathrm{H}_{2} \mathrm{O}$ ) as sole carbon sources. Cells were removed by centrifugation $(5000 \mathrm{~g}, 30 \mathrm{~min})$ and the supernatant brought to $95 \%$ saturation with ammonium sulphate at $4{ }^{\circ} \mathrm{C}$ and left stirring overnight. The precipitate was collected $(5000 \mathrm{~g}, 60 \mathrm{~min})$, resuspended in a minimal volume of cold $0.02 \mathrm{M}$-sodium phosphate buffer at $\mathrm{pH} 6.5$, and dialysed extensively against the same buffer at $4{ }^{\circ} \mathrm{C}$. After centrifugation to remove insoluble material, the preparation was lyophilised and stored at $-20{ }^{\circ} \mathrm{C}$. Protein was determined according to BRADFORD (10) using a Bio-Rad protein assay kit I with hen egg albumin as standard. Chitosanase activity was determined according to PRICE and STORCK (28). Chitosan was dissolved in $0.05 \mathrm{M}$-maleic acid to $2 \mathrm{mg} \cdot \mathrm{ml}^{-1}$, diluted 3-fold with $\mathrm{H}_{2} \mathrm{O}$ and the $\mathrm{pH}$ adjusted to 6.0 with $\mathrm{KOH}$. After preincubation of $375 \mu \mathrm{l}$ aliquots at $3 \mathrm{O}^{\circ} \mathrm{C}$ for $15 \mathrm{~min}$ the reaction was started by addition of $125 \mu \mathrm{l}$ enzyme in $0.01 \mathrm{M}$-sodium phosphate buffer $\mathrm{pH} 6.5$ giving a final volume of $500 \mu \mathrm{l}$ containing $0.5 \mathrm{mg} \cdot \mathrm{ml}^{-1}$ chitosan. After a further $15 \mathrm{~min}$ at $30{ }^{\circ} \mathrm{C}$ the reaction was stopped by addition of $100 \mu \mathrm{l} 1 \mathrm{M}-\mathrm{KOH}$ and the chitosan precipitated by incubation on ice for $30 \mathrm{~min}$. The supernatant obtained after centrifugation in an Eppendorf minifuge for $10 \mathrm{~min}$ was assayed for hexosamine content by the indole method of Dische (13). A unit of chitosanase activity was defined as the activity required to produce 1 $\mu \mathrm{mol}$ of hexosamine equivalent (mono- or oligosaccharide) per min.

\subsection{Formation of Protoplasts from Mucor}

Sporangiospores from cultures grown for 4-6 days at room temperature (mesophiles) or $37^{\circ} \mathrm{C}$ (thermophiles) on YPG pH 4.5 agar plates were harvested by gently scraping with a glass rod into distilled $\mathrm{H}_{2} \mathrm{O}$. After one wash in distilled $\mathrm{H}_{2} \mathrm{O}$ they were resuspended in YPG pH 4.5 at $10^{7} \cdot \mathrm{ml}^{-1}$ and germinated at $28{ }^{\circ} \mathrm{C}$ (mesophiles) or $25^{\circ} \mathrm{C}$ with a 2 hour preincubation at $40^{\circ} \mathrm{C}$ (thermophiles) with shaking. Ungerminated spores were removed by filtration through nylon cloth, mesh size $16 \mu \mathrm{m}$ and the germlings washed twice with $0.5 \mathrm{M}$-sorbitol. After resuspension in $0.5 \mathrm{M}$-sorbitol, $0.01 \mathrm{M}$-sodium phosphate buffer $\mathrm{pH} 6.5$ the germlings were added to an equal volume of streptozyme dissolved in the same buffer to give final concentrations of $10^{7} \cdot \mathrm{ml}^{-1}$ germlings and $0.5-1.0 \mathrm{mg} \cdot \mathrm{ml}^{-1}$ streptozyme (corresponding to approximately 1.2 units $\cdot \mathrm{ml}^{-1}$ chitosanase). After incubation at $23{ }^{\circ} \mathrm{C}$ for up to 4 hours with gentle intermittent mixing the number of protoplasts produced per $\mathrm{ml}$ was calculated by counting a minimum of two samples in a haemocytometer using phase contrast microscopy. When necessary, any undigested hyphae were removed by filtration of the protoplast suspension through nylon cloth, mesh size $10 \mu \mathrm{m}$.

\subsection{Protoplast Fusion}

Protoplasts were prepared as described in section 2.5 , and washed once with $0.01 \mathrm{M}$-sodium phosphate $\mathrm{pH}$ 6.5, $0.5 \mathrm{M}$-sorbitol. After resuspension in the same medium they were subjected to the procedure for protoplast fusion described by OHNUKI et al. (26) with minor modifications. Suspensions of protoplasts from two different auxotrophs were mixed to give a total of $10^{7}-10^{8}$ protoplast pairs then centrifuged at $400 \mathrm{~g}$ for $5 \mathrm{~min}$. The pelleted protoplasts were resuspended in $5 \mathrm{ml}$ of $45 \%$ PEG 4000 containing $60 \mathrm{mM}-\mathrm{CaCl}_{2}$ and incubated at room temperature for $30 \mathrm{~min}$. $30 \mathrm{ml}$ of $0.01 \mathrm{M}$-sodium phosphate buffer pH $6.5,0.5 \mathrm{M}$-sorbitol was added and the suspension centrifuged $(400 \mathrm{~g}, 5$ $\mathrm{min}$ ) after which the pellet was resuspended in $10 \mathrm{ml}$ of the same. $1 \mathrm{ml}$ aliquots of suitable dilutions were mixed with $9 \mathrm{ml}$ of $1 \%(\mathrm{w} / \mathrm{v})$ agar containing $0.5 \mathrm{M}$-sorbitol $\left(50^{\circ} \mathrm{C}\right)$ then overlayed onto minimal or complete agar media, $\mathrm{pH} 3.0$. Colonies were counted after two days incubation at room temperature.

\section{RESULTS AND DISCUSSION}

\subsection{Isolation of Streptozyme from}

\section{Streptomyces sp. no. 6}

Earlier reports showed that the cell walls of various members of the genus Mucor could be degraded by the cell free culture fluid of Streptomyces sp. no. $6(20,30)$ or a chitosanase purified therefrom (28). The lytic activity could be induced by growth of the Streptomyces in media containing either Mucor cell walls or chitosan 
Table I.

Comparison of crude chitosanase (streptozyme) preparations obtained from Streptomyces sp. no. 6 by three different procedures

\begin{tabular}{|c|c|c|}
\hline Method of preparation & $\begin{array}{l}\text { Yield } \\
\text { mg protein } \cdot \Gamma^{-1} \\
\text { culture }\end{array}$ & $\begin{array}{l}\text { Chitosanase } \\
\text { Specific Activity } \\
\text { units } \cdot \mathrm{mg}^{-1} \text { protein }\end{array}$ \\
\hline $\begin{array}{l}\text { As described in section } 2.4 \text {, with } 0.1 \% \\
(w / v) \text { chitosan and } 0.5 \%(w / v) \text { chitin as } \\
\text { sole C-sources in the growth media. }\end{array}$ & 205 & 2.6 \\
\hline $\begin{array}{l}\text { As described in section } 2.4 \text { but with } \\
1 \%(\mathrm{w} / \mathrm{v}) \mathrm{M} \text {. miehei cell walls } \mathrm{s}^{\mathrm{a}} \text { as sole } \\
\text { C-source in the growth media. }\end{array}$ & 47 & 1.2 \\
\hline $\begin{array}{l}\text { Incubation of stationary phase cells } \\
\text { from } 161 \text { of culture in } 21 \text { of } 0.05 \mathrm{M} \\
\text { D-glucosamine hydrochloride, } 0.1 \% \\
\text { yeast extract }{ }^{b} \text {. }\end{array}$ & 91 & 1.2 \\
\hline \multicolumn{3}{|c|}{$\begin{array}{l}\text { 2) Cell walls were prepared by grinding hyphae in liquid } \mathrm{N}_{2} \text { with a mortar and pestle followed by three passages } \\
\text { through a French pressure cell ( } 8000 \text { p.s.i.). They were then repeatedly washed with } \mathrm{H}_{2} \mathrm{O} \text { in order to remove } \\
\text { all contaminating cytoplasmic material. } \\
\text { b) According to the method of PRICE and STORCK ( } 28) \text { except that streptozyme was precipitated by addition } \\
\text { of }\left(\mathrm{NH}_{4}\right)_{2} \mathrm{SO}_{4} \text { to } 75 \% \text { saturation, chromatographed on Sephadex G-50 and then lyophilised. }\end{array}$} \\
\hline
\end{tabular}

and chitin (20), or by incubation of stationary phase cells in a medium containing $0.05 \mathrm{M}$-glucosamine (28). After a comparison of the streptozyme preparations obtained when using each of the three induction methods (Table I), the use of chitosan and chitin as sole C-sources in the

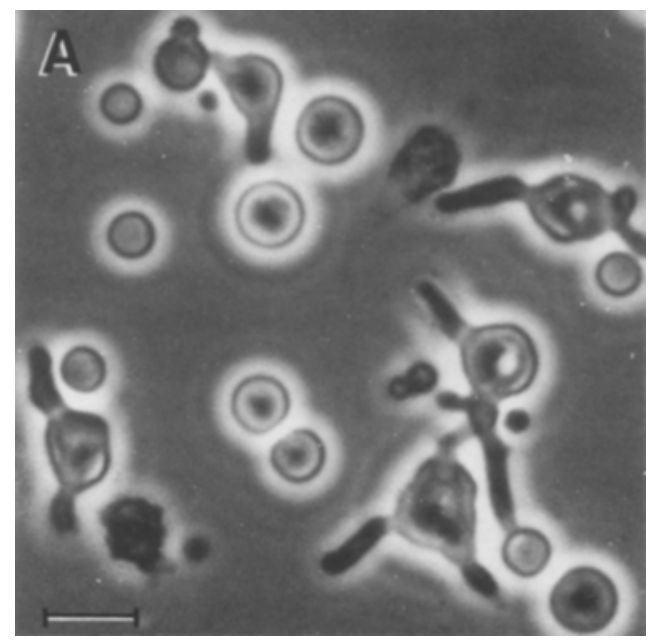

growth media was adopted as the routine procedure in this laboratory. It is the simplest procedure in practical terms and gives a streptozyme preparation whose total yield and specific activity is higher than that obtained by the other methods.

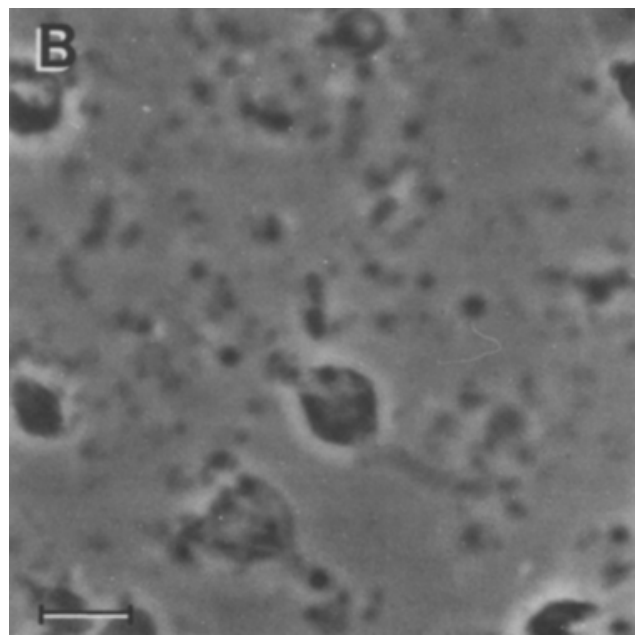

Figure 1. A. The formation of protoplasts from germlings of $\mathrm{M}$. circinelloides $\mathrm{f}$. lusitanicus upon incubation with streptozyme as described in section 2.5. B. The same field after flooding with $\mathrm{H}_{2} \mathrm{O}$ showing the osmotic sensitivity of both the protoplasts and degraded hyphae. (Bar $=10 \mu \mathrm{m})$. 


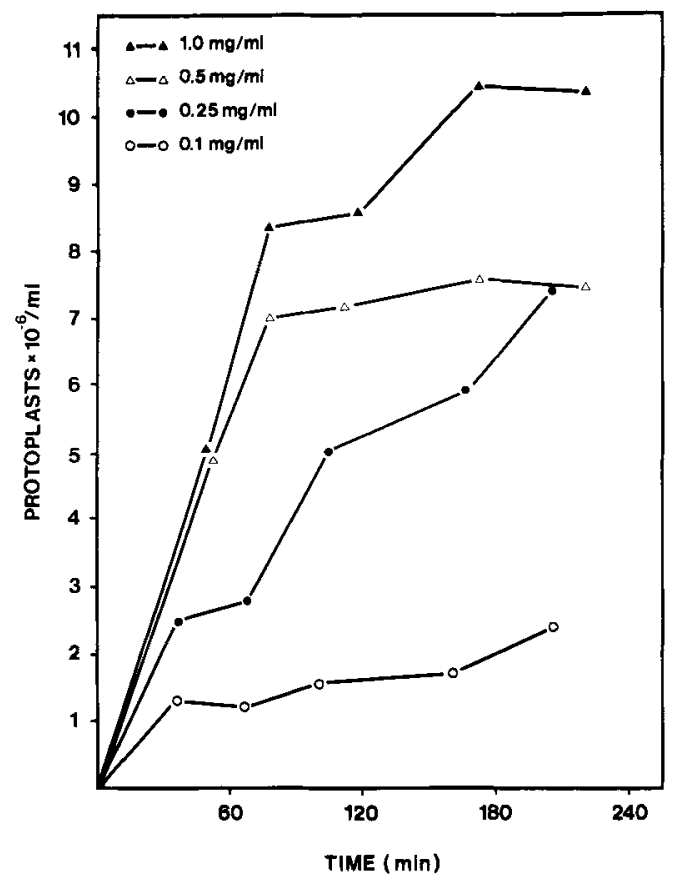

Figure 2. Effect of different concentrations of streptozyme on the formation of protoplasts of $M$. circinelloides f. lusitanicus. Method is as described in section 2.5 with the final concentration of streptozyme used as indicated. Specific activity of the streptozyme was 1.2 units chitosanase $\cdot \mathrm{mg}^{-1}$.

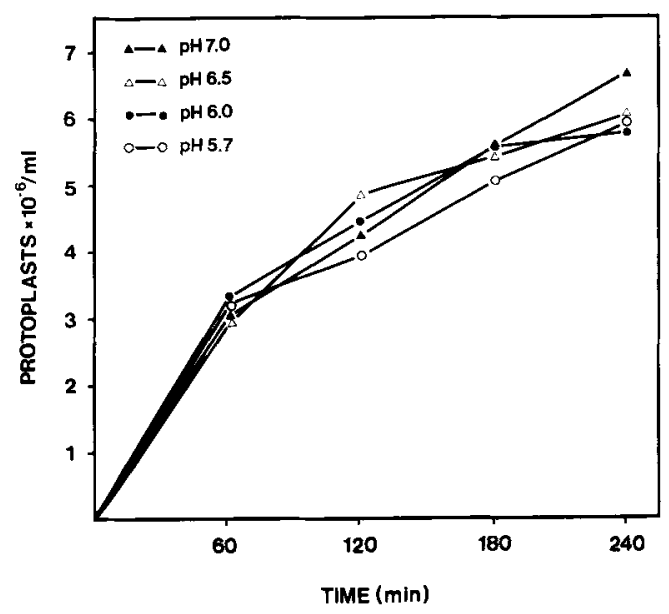

Figure 3. Effect of $\mathrm{pH}$ on the formation of protoplasts from $M$. circinelloides $f$. lusitanicus. Method is as described in section 2.5 using 0.01 M-sodium phosphate buffer at the $\mathrm{pH}$ values indicated by adjustment of the relative amounts of $\mathrm{Na}_{2} \mathrm{HPO}_{4}$ and $\mathrm{NaH}_{2} \mathrm{PO}_{4}$.

\subsection{Formation of protoplasts from $M$. circinelloides $\mathrm{f}$. lusitanicus}

When germlings of $\mathbf{M}$. circinelloides were treated with streptozyme as described in section 2.5 digestion of the cell wall occurs, the cell membrane bulges out, is pinched off, and spherical osmotically sensitive protoplasts with an average size of $7 \mu \mathrm{m}$ are released (Figure 1). The formation of protoplasts preferentially occurs at the hyphal apex which is the major site of cell wall synthesis (7). The total number of protoplasts formed varied with the conditions used, but it could be three times the total number of germlings treated. Mucor is coenocytic (i.e. has nonseptate hyphae), thus the formation of more than one protoplast per germling indicates an effective resealing of the cell membrane after a protoplast is released.

\subsubsection{Factors affecting protoplast formation}

(i) Concentration of streptozyme:

An increase in the concentration of streptozyme increased the rate of protoplast formation and the final yield of protoplasts obtained (Figure 2). When comparing different batches of streptozyme, their efficacy in producing protoplasts was directly proportional to the total chitosanase activity present. Thus, $0.5 \mathrm{mg} \cdot \mathrm{ml}^{-1}$ of a batch with a specific chitosanase activity of 2.3 produces equivalent results to $1.0 \mathrm{mg} \cdot \mathrm{ml}^{-1}$ of a batch with specific chitosanase activity of 1.2 . (ii) $\mathrm{pH}$ :

Variation of the $\mathrm{pH}$ of the phosphate buffer used during incubation within the range of $\mathrm{pH}$ 5.7-7.0 had no effect on the activity of the streptozyme (Figure 3). This is consistent with a report (28) that a chitosanase purified from Streptomyces sp. no. 6 culture fluids had optimal enzyme activity towards deacetylated chitosan over the $\mathrm{pH}$ range of 4.5-6.5. A decrease in activity was reported to occur at higher $\mathrm{pH}(28)$ but the substrate chitosan exists in a colloidal state above $\mathrm{pH} 6.5$, possibly affecting the measurement of activity. RAMIREZ-LEON and RUIZHERRERA (30) also showed that the activity of their streptozyme preparation on isolated $\mathrm{M}$. rouxii cell walls plateaued between $\mathrm{pH}$ 5.0-6.5 with one additional higher peak of activity at $\mathrm{pH}$ 7.0-7.5. 


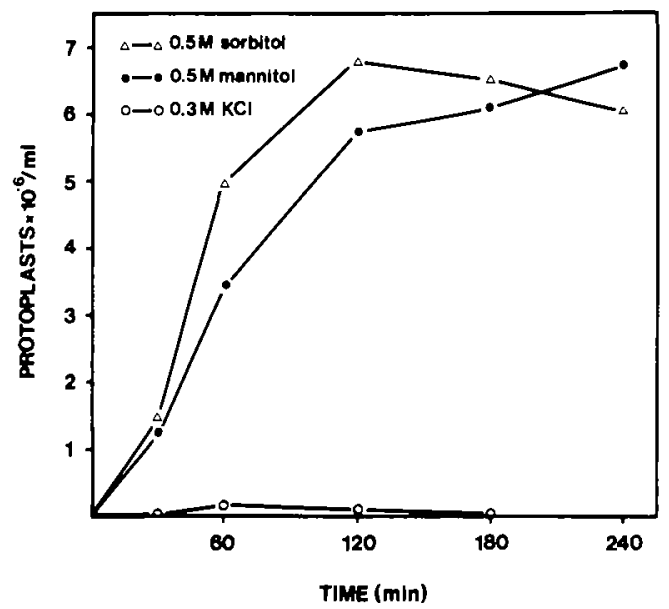

Figure 4. Use of different osmotic stabilisers in the formation of protoplasts from $M$. circinelloides $f$. lusitanicus. Method is as described in section 2.5.

(iii) Osmotic stabilisers and their concentration:

Solutions of sugar alcohols such as sorbitol and mannitol proved to be the most effective osmotic stabilisers, while use of salt solutions such as $0.3 \mathrm{M}-\mathrm{KCl}$ resulted in no protoplast formation (Figure 4). $0.3 \mathrm{M}$-solutions of $\mathrm{MgCl}_{2}$, $\left(\mathrm{NH}_{4}\right)_{2} \mathrm{SO}_{4}$ or $\mathrm{MgSO}_{4}$ were as ineffective as $\mathrm{KCl}$ and all apparently inhibit the activity of the streptozyme preparation since no cell wall degradation was observed in their presence. The optimal concentration of sorbitol was $0.35 \mathrm{M}$ $0.5 \mathrm{M}$ (Figure 5). At concentrations of $0.65 \mathrm{M}$ or higher no cell wall degradation was observed and at concentrations of $0.3 \mathrm{M}$ or lower, the action of the streptozyme was accompanied by extensive cell lysis rather than protoplast formation.

(iv) Addition of commercially available lytic enzymes:

The preparation of a lytic enzyme mixture such as streptozyme can be time consuming and different batches often vary in lytic activity. In order to circumvent such problems HAMLYN et al. (16) had investigated the possibility of using various commercially available polysaccharases in the formation of protoplasts from a range of fungi. Many preparations were found to be effective even though the active lytic components were often present only as contaminants. The effect of some of these commercially available preparations on germlings of Mucor was

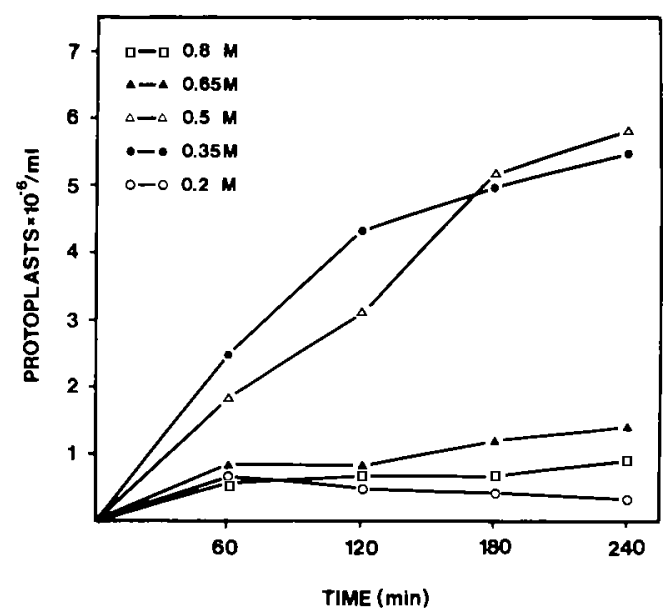

Figure 5. Effect of different concentrations of sorbitol as osmotic stabiliser on the formation of protoplasts from $M$. circinelloides f. lusitanicus. Methods as described in section 2.5 .

studied (Figure 6). None of the enzymes when used alone had any visible lytic effect, but both novozym 234 and helicase gave increased yields of protoplasts when used in combination with a low concentration of streptozyme. In contrast, the addition of chitinase, laminarinase or Penicillium $\beta$-glucanase had no effect on protoplast yields. The lack of effect of chitinase contrasts with the findings of other workers. PRICE and STORCK (28) reported that the decrease in turbidity of suspensions of Mucor cell walls after addition of the chitosanase purified from Streptomyces sp. no. 6 culture fluids was higher when a mixture of chitinase and this chitosanase was used. Similarly, the chitosanase isolated from Myxobacter AL- 1 is always used in combination with a commercially available chitinase in the formation of protoplasts from $M$. racemosus (syn. circinelloides $f$. lusitanicus, see section $2.1),(15,22)$, although the activity of the chitosanase alone is not reported. With the crude chitosanase prepared from Bacillus R-4, OHNUKI et al. (26) found the addition of chitinase and/or sulphatase essential for the production of protoplasts from M. pusillus in yields higher than 5\%. The result shown here in Figure 6 could be explained by the presence of chitinase activity in the streptozyme preparation since the 


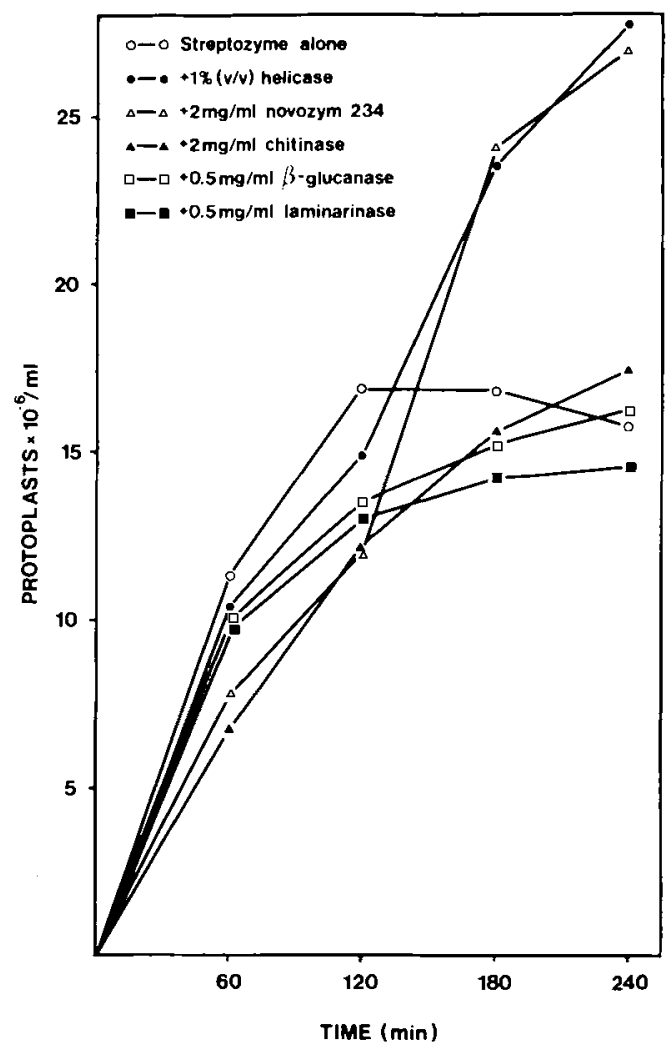

Figure 6. The effect of some commercially available lytic enzymes on the formation of protoplasts from M. circinelloides $\mathrm{f}$. lusitanicus by $0.5 \mathrm{mg} \cdot \mathrm{ml}^{-1}$ streptozyme ( 1.15 units chitosanase $\left.\cdot \mathrm{ml}^{-1}\right)$. Method is as described in section 2.5. The commercial enzymes were added to the germlings at the same time as the streptozyme and to the final concentrations indicated.

growth media for streptozyme production contains both chitin and chitosan.

(v) Extent of germination

Ungerminated sporangiospores were totally resistant to the lytic action of the streptozyme. This resistance was lost upon germination, but was acquired again, though to a lesser extent, as the hyphae aged and grew in length. The effect that these changes in cell wall sensitivity have upon the formation of protoplasts is shown in Figure 7. The yield of protoplasts obtained was highest when germlings had a germ tube length of 35-50 $\mu \mathrm{m}$. Below this size, digestion of the cell wall at the growing hyphal tip still occurred but the amount of material extruded was decreased,

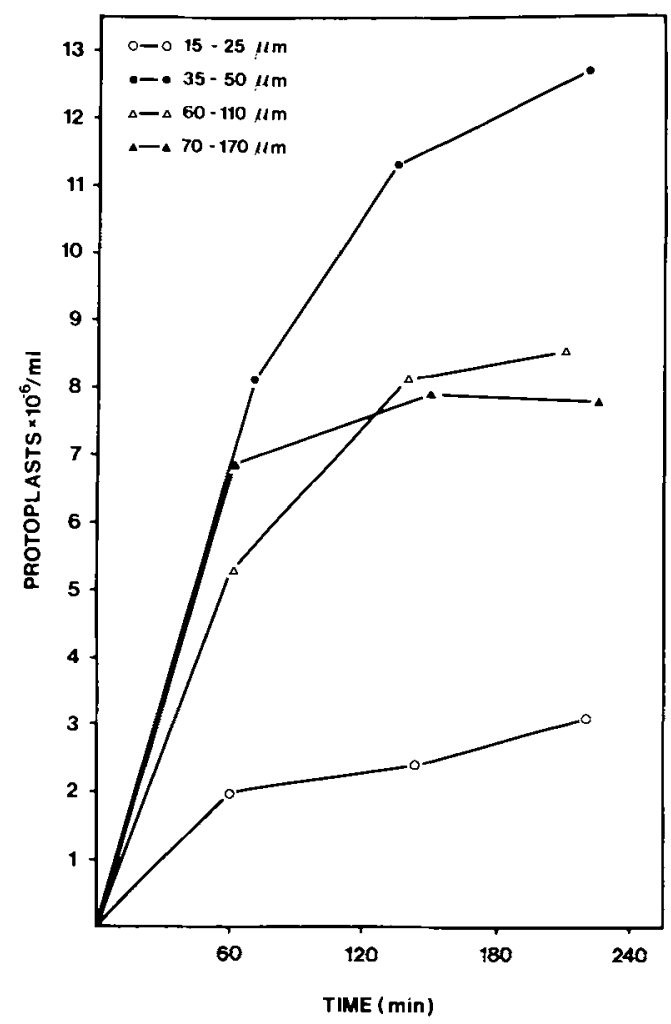

Figure 7. The influence of germ tube length on the formation of protoplasts from $M$. circinelloides $f$. lusitanicus. Sporangiospores were germinated until the distance from spore center to hyphal tip was as indicated when they were harvested and treated as described in section 2.5 .

with a consequent reduction in the number of protoplasts formed. When the germ tube length exceeded approximately $60 \mu \mathrm{m}$, the amount of hyphal structure visibly resistant to streptozyme action increased, the protoplast yield decreased, and the homogeneity of the protoplasts obtained also decreased (as evidenced by a greater variation in size, refractility and apparent membrane integrity).

A high yield of morphologically homogeneous protoplasts thus requires that the suspension of germlings to be treated with streptozyme is relatively homogeneous with respect to extent of germination (i.e., germ tube length). In the related genus Phycomyces, synchronous germination can be induced by various treatments such as heat shock $\left(48{ }^{\circ} \mathrm{C}\right.$ for $\left.3 \mathrm{~min}\right)(8)$. 


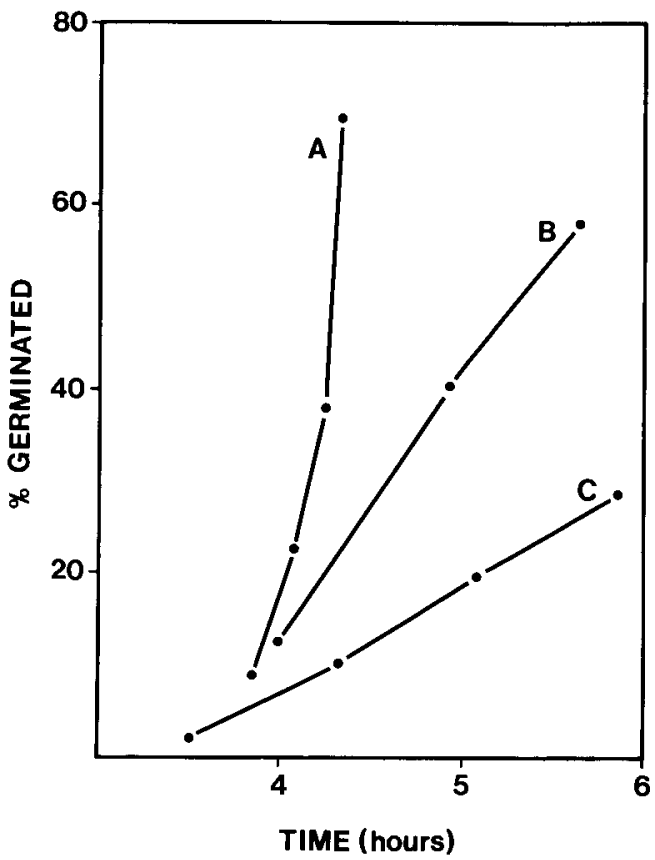

Figure 8. Germination of sporangiospores of M. miehei CBS 370.65 in liquid media at $40^{\circ} \mathrm{C}$. Sporangiospores were harvested from fresh cultures on agar plates (A and B) or obtained from $\mathrm{H}_{2} \mathrm{O}$ suspensions stored frozen at $-20^{\circ} \mathrm{C}(\mathrm{C})$. They were incubated with shaking at a density of $10^{7} \cdot \mathrm{ml}^{-1}$ in YPG pH $4.5(\mathrm{~A})$ or YNB $\mathrm{pH} 4.5$ (B and $\mathrm{C}$ ) with a total of $10 \mathrm{ml}$ media per $250 \mathrm{ml}$ Ehrlenmyer flask. A spore was judged to have germinated when the length of the germ tube was equal to its breadth. When more than $60 \%$ of the spores had germinated the accuracy of counting was reduced due to extensive clumping of the germlings.

Unfortunately no specific induction methods are known for Mucor. Germination is generally asynchronous but can be improved by manipulation of the culture conditions. The germination of freshly harvested sporangiospores in a complete media was more synchronous than when using frozen spores or a minimal growth media (Figure 8). A 10-fold reduction in spore density, or a 10-fold increase in the ratio of flask volume to liquid volume gave no further improvement. Use of $0.1 \mathrm{M}$-phosphate buffer $\mathrm{pH} 6.5$ containing $0.01 \mathrm{M}$-proline, which is reported to induce synchronous germination in the related genus RHIzOPUS (41), initiated no growth at all. Short incubations ( $15 \mathrm{~min}$ ) at temperatures of up to $95^{\circ} \mathrm{C}$ had no effect, but generally the closer the incubation temperature is to the optimal growth temperature the more synchronous is the germination. This can be seen most clearly with the thermophilic species, an example of which is shown in Figure 9. Here the sporangiospores of M. miehei CBS 182.67 can be seen to germinate rapidly (within 5 hours) and relatively synchronously when incubated at $40{ }^{\circ} \mathrm{C}$, but when incubated at the sub-optimal temperature of 25 ${ }^{\circ} \mathrm{C}$ they germinate slowly, extremely asynchronously and many remain ungerminated even after 28 hours incubation. STREETS and INGLE (38) had previously shown that little germination and growth occurred at $25^{\circ} \mathrm{C}$ in a strain of M. miehei (NRRL-3420) whose optimal temperature for spore germination was $45^{\circ} \mathrm{C}$. However, substantial growth occurred at $25^{\circ} \mathrm{C}$ if a 10 hour preincubation step at $37^{\circ} \mathrm{C}$ was introduced, during which time spore germination was completed (38). Figure 9 shows that preincubation at $40{ }^{\circ} \mathrm{C}$ for only $2-3$ hours significantly increased both the speed and synchrony of subsequent germination at $25^{\circ} \mathrm{C}$. During such short times at $40^{\circ} \mathrm{C}$ the spores begin to swell, but the emergence of germ tubes does not occur until some hours later, during incubation at the lower temperature. These regimes are useful, therefore, in studies where sub-optimal growth temperatures are required (see section 3.3).

\subsubsection{Regeneration of protoplasts on solid media}

The protoplasts of $M$. circinelloides $f$. lusitanicus were stable and regenerated at frequencies of up to $40 \%$ even after overnight incubation at $4{ }^{\circ} \mathrm{C}$ in $0.01 \mathrm{M}$-sodium phosphate buffer $\mathrm{pH}$ $6.5,0.5 \mathrm{M}$-sorbitol. A comparison of different plating conditions for the regeneration of these protoplasts on solid media $(2 \%(\mathrm{w} / \mathrm{v})$ agar) showed that a $1 \%$ agar overlay consistently gave better results (Table II). Direct spreading of protoplast suspensions onto plates with considerable surface moisture produced equivalently good regeneration but is not preferred because cells clumped and floated on the plate surface, reducing the accuracy of colony counts and hindering the isolation of single clonal colonies. A further disadvantage was the necessity to monitor the amount of moisture on the plates, 


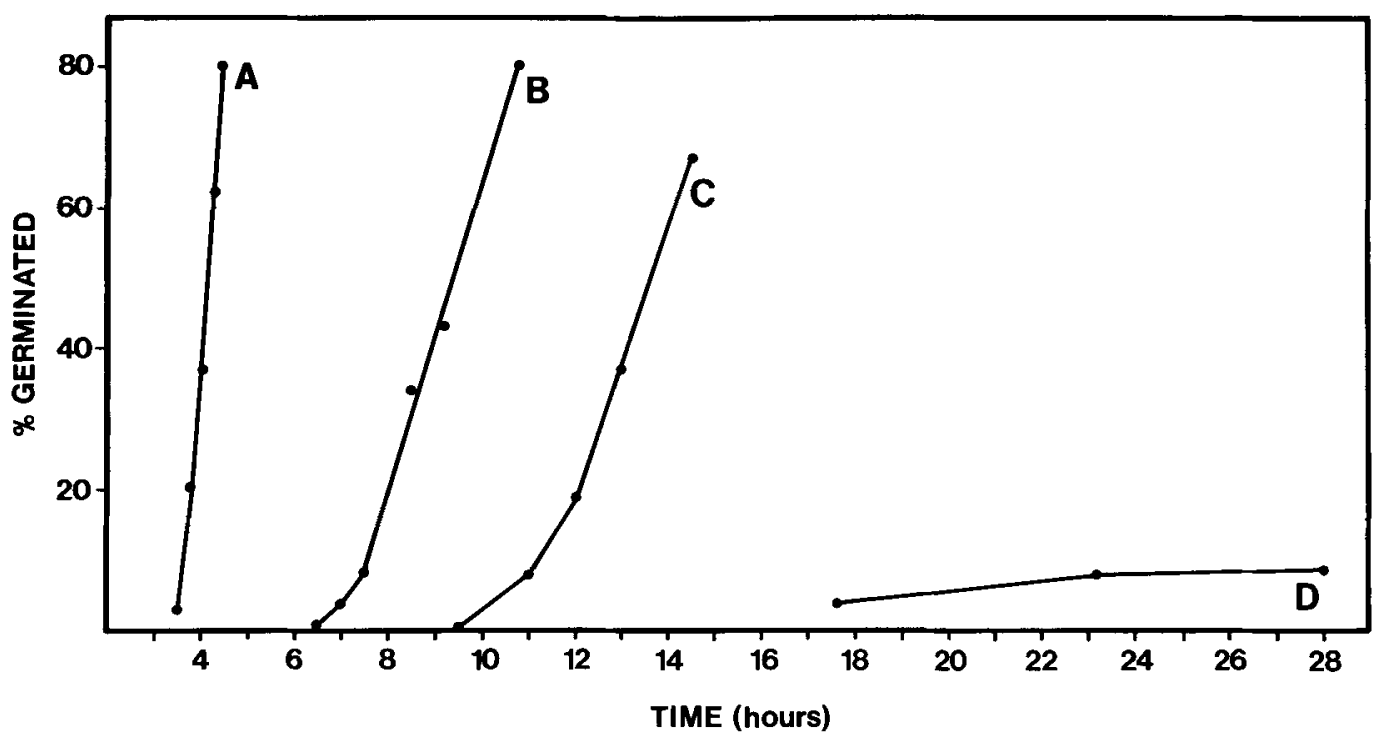

Figure 9. Germination of sporangiospores of M. miehei CBS 182.67 at $25{ }^{\circ} \mathrm{C}$ after preincubation at $40{ }^{\circ} \mathrm{C}$ for 3 hours (B) or 2 hours (C). Curves (A) and (D) show germination after incubation at $40{ }^{\circ} \mathrm{C}$ and $25{ }^{\circ} \mathrm{C}$, respectively.

since drying of the surface resulted in a reduced frequency of regeneration (see Table II). Alteration of the $\mathrm{pH}(\mathrm{pH} 3.0-\mathrm{pH} 4.5)$, or use of the defined media YNB instead of YPG produced no significant differences. The figures given in Table II are the results from a single experiment. The absolute values of regeneration can vary somewhat from time to time but the trends remain the same.

\subsubsection{Fusion of protoplasts}

The fusion of protoplasts prepared from auxotrophic strains was achieved using $45 \%(\mathrm{w} / \mathrm{v})$ PEG 4000 and $60 \mathrm{mM}-\mathrm{CaCl}_{2}$ according to the

Table II.

Regeneration of protoplasts of $M$. circinelloides on solid media

\begin{tabular}{ll}
\hline Plating conditions & Regeneration $(\%)^{\text {b) }}$ \\
\hline $1 \%(w / v)$ agar overlay $\left(50^{\circ} \mathrm{C}\right)$ & 39 \\
$3 \%(w / v)$ agar overlay $\left(50^{\circ} \mathrm{C}\right)$ & 11 \\
$1 \%(w / v)$ low melting point agar overlay $\left(36^{\circ} \mathrm{C}\right)$ & 26 \\
Freshly prepared agar plates with a moist surface & 31 \\
Agar plates with dried surface & 7 \\
\hline
\end{tabular}

${ }^{3}$ ) A suspension of protoplasts prepared from M. circinelloides f. lusitanicus CBS 277.49 as described in section 2.5 was diluted in $0.5 \mathrm{M}$-sorbitol, $0.01 \mathrm{M}$-sodium phosphate buffer $\mathrm{pH} 6.5$ then plated onto YPG pH 3.0 agar plates by mixing $1 \mathrm{ml}$ with $9 \mathrm{mls}$ of an agar overlay (held molten at the temperature indicated), or by directly spreading $1 \mathrm{ml}$ or $0.5 \mathrm{ml}$ (moist or dry surface plates, respectively) onto the plate surface. All plates and overlay solutions contained $0.5 \mathrm{M}$-sorbitol as osmotic stabiliser unless otherwise stated.

b) Regeneration (\%) was calculated by dividing the number of colonies obtained by the total number of protoplasts plated (determined by counting in a haemocytometer). Correction was made for the presence of non-osmotically sensitive cells (undegraded hyphae and sporangiospores) which represented approximately $1.5 \%$ of the total count. 
Table III.

Fusion of protoplasts of auxotrophs of $M$. circinelloides)

\begin{tabular}{lll}
\hline Strains fused & Ile 4A $\times$ Met 5A & Cys 1A $\times$ Leu 7B \\
\hline No. of protoplast pairs (A) & $6.5 \times 10^{7}$ & $2.8 \times 10^{7}$ \\
C.f.u." on minimal medium (B) & $2.3 \times 10^{5}$ & $1.3 \times 10^{5}$ \\
C.f.u. on complete medium (C) & $1.6 \times 10^{7}$ & $7.8 \times 10^{6}$ \\
Fusion frequency (B/C) & $1.4 \%$ & $1.7 \%$ \\
No. heterokaryons formed per protoplast pair (B/A) & $3.5 \times 10^{-3}$ & $4.6 \times 10^{-3}$ \\
Regeneration frequency (C/A) & $24.6 \%$ & $27.8 \%$ \\
\hline
\end{tabular}

${ }^{a}$ Protoplast fusion was carried out as described in section 2.6 using the number of protoplast pairs given above.

${ }^{\text {b) }}$ C.f.u. = colony forming units after protoplast fusion.

method of OHNUKI et al. (26). The fusion frequencies obtained (Table III) are comparable with the frequencies of $1-6 \%$ reported by

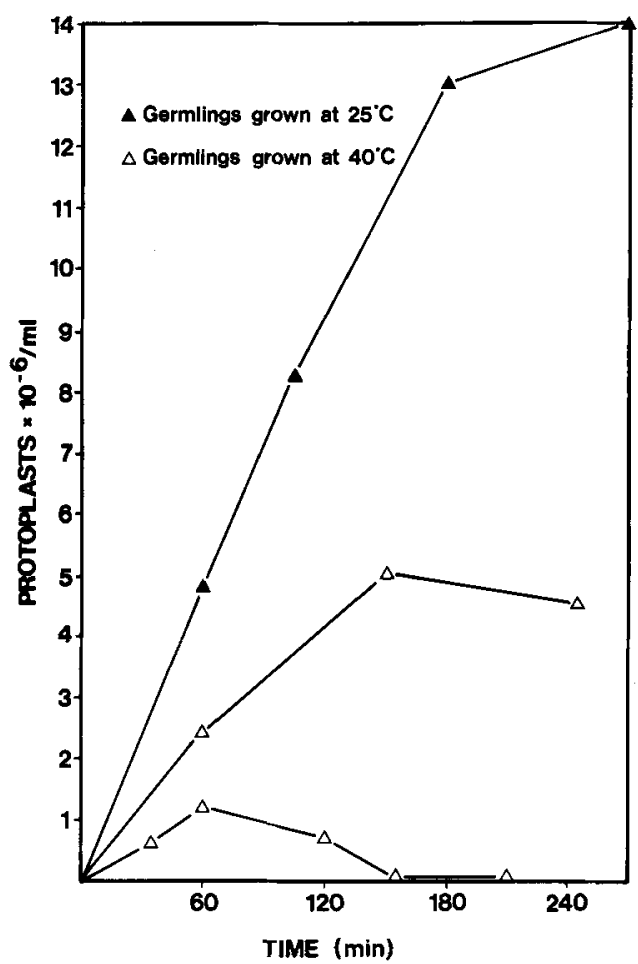

Figure 10. Effect of growth temperature on the formation of protoplasts from M. miehei CBS 182.67 . Method is as described in section 2.5 using germlings grown at $40^{\circ} \mathrm{C}$, or $25^{\circ} \mathrm{C}$ with a 2 hour preincubation at $40^{\circ} \mathrm{C}$. The results of two seperate experiments using germlings grown at $40{ }^{\circ} \mathrm{C}$ are presented to illustrate the variations obtained.
LASKER and BORGIA (22) using their own auxotrophs of the same strain of Mucor, but they are considerably lower than the $5-40 \%$ obtained by OHNUKI et al. (26) using auxotrophs of the thermophiles $M$. pusillus and $M$. miehei. The total number of heterokaryons formed per protoplast pair, on the other hand, are at least one order of magnitude higher for $\mathrm{M}$. circinelloides (Table III) than for M. miehei and M. pusillus where the frequencies were only $0.35-2.5 \times 10^{-4}$ (26). Initially it seems somewhat contradictory that the thermophiles give lower total yields of heterokaryons than $\mathrm{M}$. circinelloides in spite of their higher fusion frequencies. This contradiction can be explained however by their extremely low regeneration frequencies $(0.017$ $0.096 \%$ when calculated as in Table III using the data provided in Table I of ref. 26). These protoplasts were produced from germlings grown at $37{ }^{\circ} \mathrm{C}$ and this low degree of regeneration confirms the observations presented here (section 3.3) that the thermophilic species must be grown at lower temperatures in order to produce more stable protoplasts.

\subsection{Formation of protoplasts from other Mucor species: The influence of growth temperature.}

Treatment of the mesophiles $M$. racemosus no. 50 and $M$. rouxii with streptozyme as described in section 2.5 resulted in the formation of protoplasts similar in yield and properties to those of $M$. circinelloides $f$. lusitanicus (section 3.2). When using the thermophilic strains $M$. 

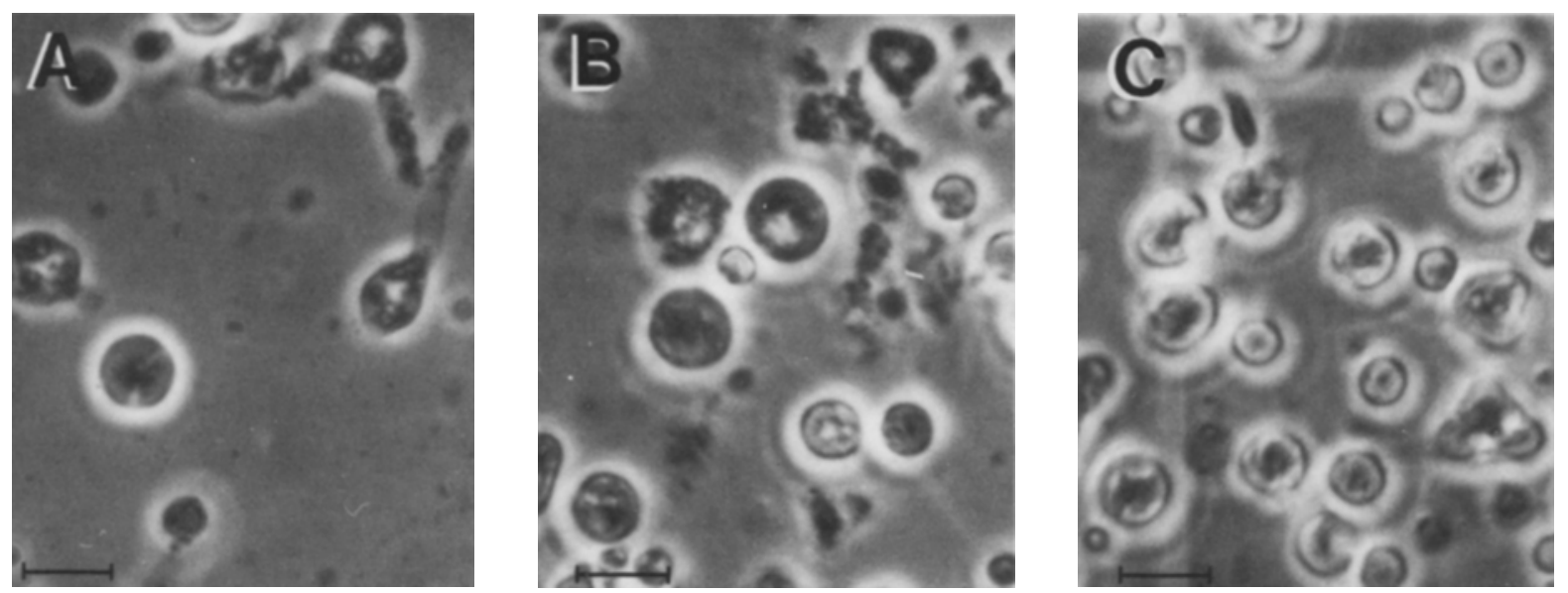

Figure 11. Protoplasts formed from M. miehei CBS 182.67 grown at $40{ }^{\circ} \mathrm{C}$ (A and B), or $25{ }^{\circ} \mathrm{C}$ with a 2 hour preincubation at $40^{\circ} \mathrm{C}(\mathrm{C}) .(\mathrm{Bar}=10 \mu \mathrm{m})$. The photographed samples were taken from the protoplast suspensions represented in Figure 10 after $240 \mathrm{~min}$ of incubation; in the case of the germlings grown at 40 ${ }^{\circ} \mathrm{C}, \mathrm{A}$ and $\mathrm{B}$ represent the lower and upper curves respectively. The protoplasts regenerated at frequencies of $.003 \%(\mathrm{~A}), .17 \%(\mathrm{~B})$ and $3.5 \%$ (C) (determined as described in Table II using $1.0 \%(\mathrm{w} / \mathrm{v}$ ) agar overlays).

miehei CBS 182.67, M. miehei CBS 370.65 and M. pusillus IMI 96211 an effect of the growth temperature on the ability to form stable protoplasts was observed. Growth of the germlings at $25^{\circ} \mathrm{C}$ prior to streptozyme treatment reproducibly enabled the subsequent isolation of high yields of protoplasts (Figure 10) of homogeneous morphology and with regeneration frequencies of $3-6 \%$ (Figure $11-C$ ). When the germlings were grown at $40{ }^{\circ} \mathrm{C}$ more variable results were obtained and the final yields of protoplasts were reduced to $10^{5}-5 \times 10^{6} \cdot \mathrm{ml}^{-1}$ (Figure 10 ). The stability of these protoplasts was decreased, as evidenced by the low regeneration frequencies of .003-.3\%. Their morphological heterogeneity in terms of size and refractility was increased and the extensive lysis of both hyphae and protoplasts was observed by phase contrast microscopy (Figures 11-A and B). The instability of the protoplasts formed from thermophilic species grown at $37^{\circ} \mathrm{C}$ is also indicated in the data of OHNUKI et al. (26) (see section 3.2.3). The deleterious effects described above were aggravated by incubation of the germlings grown at $40{ }^{\circ} \mathrm{C}$ for $10-20 \mathrm{~min}$ at $4{ }^{\circ} \mathrm{C}$, prior to the incubation at $23{ }^{\circ} \mathrm{C}$ with the streptozyme solution. Incubation of cells at low nonfreezing temperatures below growth temperature can lead to physiological dysfunction, the critical temperature for injury being determined by the gel to liquid-crystalline phase transition temperature of the membrane lipids $(21,23)$. Incubation at or below the phase transition temperature results in decreased membrane fluidity, altered activities of membrane bound enzymes, increased membrane permeability and eventually in the injury and death of cells and tissues (21, 23). The instability of the protoplasts from Mucor germlings grown at $40{ }^{\circ} \mathrm{C}$ might thus reflect injury caused by exposure to the lower temperature(s) of $23^{\circ} \mathrm{C}$ (and $4{ }^{\circ} \mathrm{C}$ ). Growth of these strains at $25^{\circ} \mathrm{C}$ might produce physiological changes conferring increased resistance of the cells (and protoplasts) to damage at these temperatures. A decrease in growth temperature is known to be paralleled by a decrease in membrane lipid phase transition temperatures in many different cell types $(1,25,29,40)$ possibly due to the adjustment of the degree of unsaturation of the fatty acid chains of the membrane phospholipids. Decreased growth temperatures have been shown to result in a decrease in the molar ratio of saturated: unsaturated fatty acids in the same cell types $(1,25$, 29, 32) and in the thermophilic Mucor species M. miehei and M. pusillus (39). 


\section{ACKNOWLEDGEMENTS}

Thanks are due to members of the Department of Physiology for their helpful discussions throughout this work. In particular thanks go to ANETTE H. JøRGENSEN for excellent technical assistance, P.B. HøJ and D.J. SIMPSON for critical reading of the manuscript and NINA RASMUSSEN for drawing the figures.

\section{REFERENCES}

1. ABbas, C.A. \& G.L. CARD: The relationships between growth temperature, fatty acid composition and the physical state and fluidity of membrane lipids in Yersinia enterocolitica. Biochim. Biophys. Acta. 602, 469-476 (1980)

2. ADAMS, P.R. \& J.J. DePloEY: Amylase production by Mucor miehei and Mucor pusillus. Mycologia 68, 934-938 (1976)

3. Arima, K., S. Iwasaki \& G. Tamura: Milk-clotting enzyme from microorganisms. V. Purification and crystallization of Mucor rennin from Mucor pusillus var. Lindt. Appl. Microbiol. 16, 17271733 (1968)

4. Bartnicki-Garcia. S.: Symposium on biochemical bases of morphogenesis in fungi. III. Moldyeast dimorphism of Mucor. Bacteriol. Rev. 27, 293-304 (1963)

5. BartNicki-GarCia, S.: Cell wall chemistry, morphogenesis and taxonomy of fungi. Ann. Rev. Microbiol. 22, 88-108 (1968)

6. Bartnicki-Garcia, S., N. Nelson \& E. Cota-RoBLES: Electron microscopy of spore germination and cell wall formation in Mucor rouxii. Arch. f. Mikrobiol. 63, 242-255 (1968)

7. Bartnicki-Garcia, S. \& E. Lippman: Fungal morphogenesis: Cell wall construction in Mucor rouxii. Science 165, 302-304 (1969)

8. Bergman, K., P.V. Burke, E. Cerda-Olmedo, - C.N. David, M. Delbruck, K.W. Foster, E.W. GoOdell, M. HeisenberG, G. Meissner, M. ZALOKAR, D.S. DENNISON \& W. SHROPSHIRE JR. Phycomyces. Bacteriol. Rev. 33, 99-157 (1969)

9. Binding, H. \& H.J. Weber: The isolation, regeneration and fusion of Phycomyces protoplasts. Molec. Gen. Genet. 135, 273-276 (1974)

10. BRADFORD, M.M: A rapid and sensitive method for the quantification of microgram quantities of protein utilizing the principle of protein dye binding. Anal. Biochem. 72, 248-254 (1976)

11. BULL, A.T.: Inhibition of polysaccharases by melanin: Enzyme inhibition in relation to mycolysis. Arch. Biochem. Biophys. 137, 345-356 (1970)
12. CutTer, JR., V.M.: Nuclear behaviour in the Mucorales. I. The Mucor pattern. Bulletin of the Torrey Botanical Club. 69, 480-508 (1942)

13. Dische, Z: New color reactions for determination of sugars in polysaccharides. In: Methods of Biochemical Analysis. D. Glick ed. Interscience Publishers Inc., New York. Vol. 2, pp. 313-358 (1955)

14. Gauger, W.: The germination of zygospores of Mucor hiemalis. Mycologia. 57, 634-641 (1965)

15. Genthner, F.J.\&P.T.Borgia: Spheroplast fusion and heterokaryon formation in Mucor racemosus. J. Bacteriol. 134, 349-352 (1978)

16. Hamlyn, P.F., R.E. Bradshaw, F.M. Mellon, C.M. Santiago, J.M. Wilson \& J.F. Peberdy: Efficient protoplast isolation from fungi using commercial enzymes. Enzyme Microb. Technol. 3, 321-325 (1981)

17. HeDGES, A. \& R.S. WolfE: Extracellular enzyme from Myxobacter AL-1 that exhibits both $\beta-1,4$ glucanase and chitosanase activities. J. Bacteriol. $120,844-853$ (1974)

18. HeEswiJCK, R. VAN \& M.I.G. RONCERO: High frequency transformation of Mucor with recombinant plasmid DNA. Carlsberg Res. Commun. 49, $691-702$ (1984)

19. Higashio, K. \& Y. Yoshioka: Screening test and identification of a potent fungus for producing milk clotting enzyme and improvement of its enzymatic properties by using mutants of the fungus. Nippon Nogeikagaku Kaishi. 55, 561-571 (1981)

20. JONES, D., J.S.D. BACON, V.C. FARMER \& D.M. WEBLEY: Lysis of cell walls of Mucor ramannianus Moller by a Streptomyces sp. J. Microbiol. \& Serol. 83, 173-182 (1968)

21. KARP, G.: Membrane structure and function. Chap. 5 in Cell Biology, 2nd Ed. McGraw-Hill (1984)

22. LASKER, B.A. \& P.T. BorgIA: High-frequency heterokaryon formation by Mucor racemosus. J. Bacteriol. 141, 565-569 (1980)

23. LyONS, J.M.: Chilling injury in plants. Ann. Rev. Plant Physiol. 24, 445-466 (1973)

24. Monaghan, R.L., D.E. Eveleigh, R.P. Tewari \&E.T. REESE: Chitosanase, a novel enzyme. Nature New Biology. 245, 78-80 (1973)

25. Nakayama, H., T. Mitsui, M. Nishihara \& $M$. KITO: Relation between growth temperature of E. coli and phase transition temperatures of its cytoplasmic and outer membranes. Biochim. Biophys. Acta 601, 1-10 (1980)

26. OHNUKI, T., Y. ETOH \& T. BEPPU: Intraspecific and interspecific hybridisation of Mucor pusillus and Mucor miehei by protoplast fusion. Agric. Biol. Chem. 46, 451-458 (1982) 
27. Ottesen. M. \& W. Rickert: The isolation and partial characterisation of an acid protease produced by Mucor miehei. Compt. Rend. Trav. Lab. Carlsberg. 37, 301-325 (1970)

28. Price, J.S. \& R. Storck: Production, purification and characterisation of an extracellular chitosanase from Streptomyces. J. Bacteriol. 124, 15741585 (1975)

29. Raison, J.K., C.S. Pike \& J.A. Berry: Growth temperature-induced alterations in the thermotropic properties of Nerium oleander membrane lipids. Plant Physiol. 70, 215-218 (1982)

30. Ramirez-LeON I.F. \& J. RuIZ-HerRERA: Hydrolysis of walls and formation of sphaeroplasts in Mucor rouxii. J. Gen. Microbiol. 72, 281-290 (1972)

31. RonCERo, M.I.G.: Enrichment method for the isolation of auxotrophic mutants of Mucor using the polyene antibiotic N-glycosyl-polifungin. Carlsberg Res. Commun. 49, 685-690 (1984)

32. Sato, N., N. Murata, Y. Miura \& N. Ueta: Effect of growth temperature on lipid and fatty acid compositions in the blue-green algae, Anabena variabilis and Anacystis nidulans. Biochem. Biophys. Acta. 572. 19-28 (1979)

33. SChipper, M.A.A.: On Mucor circinelloides, Mucor racemosus and related species. Studies in Mycology 12,1-40 (1976)

34. SCHIPPER, M.A.A.: On certain species of Mucor with a key to all accepted species. Studies in Mycology 17, 1-52 (1978)
35. Skujins, J.J., H.J. Potgieter \& M. Alexander: Dissolution of fungal cells by a Streptomycete chitinase and $\beta(1-3)$ glucanase. Arch. Biochem. Biophys. 111, 358-364 (1965)

36. Somkuti, G.A.: Synthesis of cellulase by Mucor pusillus and Mucor miehei. J. Gen. Microbiol. 81, 1-6 (1974)

37. Somkutr. G.A. \& F.J. Babel: Lipase activity of Mucor pusillus. Appl. Microbiol. 16, 617-619 (1968)

38. Streets, B.W. \& M.B. Ingle: The effect of temperature on spore germination and growth of Mucor miehei in submerged cultures. Can. J. Microbiol. 18, 975-979 (1972)

39. Sumner, J.L. \& E.D. Morgan: The fatty acid composition of sporangiospores and vegetative mycelium of temperature-adapted fungi in the order Mucorales. J. Gen. Microbiol. 59, $215-221$ (1969)

40. Tsukamoto, Y., T. Ueki. T. Mitsui. T.-A. ONo \& N. MURATA: Relationship between growth temperature of Anacystis nidulans and phase transition temperature of its thylakoid membranes. Biochim. Biophys. Acta. 602, 673-675 (1980)

41. WEBER, D.J. \& J.M. OGawa: The specificity of proline in the germination of spores of Rhizopus arrhizus. Phytopathology 55, 262-266 (1965)

42. Wurtz, T. \& H. Jockusch: Morphogenesis in Mucor mucedo: Mutations affecting gamone response and organ differentiation. Molec. Gen. Genet. 159, 249-257 (1978) 